\title{
Institutional density and public policies in two cases of geographical indications from Mexico and Spain
}

\section{Mario Fernández-Zarza ${ }^{1}$ (D) | Santiago Amaya-Corchuelo ${ }^{2}$ | Encarnación Aguilar Criado ${ }^{3}$ (D)}

\author{
${ }^{1}$ Department of Social Anthropology, \\ University of Seville, C/Doña María de Padilla, \\ $\mathrm{s} / \mathrm{n}$, Seville 41004, Spain \\ ${ }^{2}$ Department of General Economy, University \\ of Cádiz, Enrique Villegas Vélez, 2, Cádiz \\ 11002, Spain \\ ${ }^{3}$ Department of Social Anthropology, \\ University of Seville, C/Doña María de Padilla, \\ s/n, Seville 41004, Spain

\section{Correspondence} \\ Encarnación Aguilar Criado. Department of \\ Social Anthropology, University of Seville, C/ \\ Doña María de Padilla, s/n, Seville 41004, \\ Spain. \\ Email: eaguilar@us.es
}

Funding information

Ministerio de Economía y Competitividad, Grant/Award Number: CSO2013-42468-P

\begin{abstract}
This study analyses the role of private and/or public institutions on achieving success in projects aiming to obtain certification labels for local food products. This analysis is performed through comparative framework provided by 2 specific study cases; 1 from Mexico, based on the production of a type of traditional spicy pork sausage, or chorizo, and another from Spain, on the production of Iberian ham. A mixed methodology has been used to perform an in-depth analysis of socio-political contexts by distinguishing the divergent institutional frameworks of both cases. The study will contribute to connecting the results of these initiatives to the institutional density in which both proposals are originated and are implemented. From there, the text explores the reasons for success, stagnation, and/or failure of these actions. These empirical data constitute an important contribution to the analysis of geographical indications and diverse sociological universes supporting the differentiation of agrifood quality certification.
\end{abstract}

\section{KEYWORDS}

geographical indications, institutional density, public policies, rurality, territory

Funding: This research is the outcome of the project (CSO2013-42468-P) "Quality brands in the rural world: new challenges for producers and consumers." This study was supported by Spanish Ministerio de Economáa y Competitividad. 


\section{1 | INTRODUCTION}

The recent increase in agrifood quality certifications, such as geographical indications (Gls), has been the subject of extensive scientific literature. Defining this term is complex, as it has been applied in different sociological contexts. Recent studies, such as Drivas and lliopoulos (2017), acknowledge its broadness, and, based on the World Trade Organization and Trade Related Intellectual Property Rights treaties, they define Gls as agrifood products originating in a specific territory, region, or locality. The link between product and territory is at the core of its definition, as the product's qualities are ascribed to the specific geographical context in which it originates. These products must meet three fundamental criteria: (a) the specific use of local resources within production processes; (b) the historical connection to the territory-including the tradition of producing and consuming it; and (c) the collective dimension of a localized know-how (Belletti, Marescotti, \& Brazzini, 2017).

In this manner, Gls can be certified by one of the following quality food labels: protected designation of origin (PDO), protected geographical indication (PGI), traditional speciality guaranteed (TSG), fair trade, ${ }^{1}$ and collective marks $(C M)^{2}$-as in the Mexican case that will be discussed in this paper. One of the main explicit functions of these GI labels is maintaining product quality and conserving traditional production expertise. Therefore, they appear as guarantees for the conservation of patrimonial values related to these products, associating the product with its territory of origin, adding value that differentiates it from others, and enabling the opening of a market niche in an increasingly competitive world.

In fact, the origin of these quality food certifications is mostly located in Europe, and it is linked to the wine industry. Nevertheless, over time, it would spread to other products and geographical areas; modifying its regulation under various international agreements within a changing global economic context. Its history goes back to the Paris agreement that, at the end of the 19th century, made official the concept of "Indications of Origin," to combat wine fraud (WIPO, 2017c). Afterwards, the Lisbon Agreement, in 1958, and its later modifications as the Madrid Protocol in 1989 (WIPO, 2017b) redefined these concepts within a new global scenario, setting up standardized procedures and broadening its vision beyond the strict European reality to adapt them to the reality of non-European countries.

At the end of the last century, the pursuit of food quality certifications was a sustained activity in many countries. Diverse public policies were implemented in an attempt to mitigate the impact that technological changes and industrial inputs had on traditional agriculture. This productivist logic would lead to market saturation and provoke negative environmental effects. However, although in several countries such as Japan, the United States, or Mexico itself, a type of production started that was linked to international guidelines for standardized food quality that were based on food safety principles (Brunsø, Fjord, \& Grunert, 2002; Grunert, 2005); in Europe, local food products with territorial quality, protected by Gls, would increase their market presence (Amaya-Corchuelo \& Aguilar, 2012; Bertozzi, 1995; Tregear, Arfini, Belletti, \& Marescotti, 2007; Vandecandelare, Arfini, Belletti, \& Marescotti, 2010).

Therefore, there are countless experiences to demonstrate the wide range of situations and cases of Gls in which each process and context requires specific analysis. There exists a wide literature dedicated to the study of the legislative aspects of international treaties ${ }^{3}$ that support these certifications (Drivas \& lliopoulos, 2017; Peralta, 2010), showing the experiences in obtaining and registering Gls (Belletti, Marescotti, \& Touzard, 2015; Poméon, Barragán, Boucher, \& Cervantes, 2011; Qui ones-Ruiz et al., 2016). Other authors link Gls to good production practices

\footnotetext{
${ }^{1}$ This certification is used in Southern countries. This is how products are specified internationally for guaranteeing their territorial linkage and, in general, they tend to have a historical link. Moreover, they have the social responsibility of paying the local producers fairly.

${ }^{2} \mathrm{CM}$ are considered under the intellectual property law of most countries and under the Madrid Protocol (1989). They are usually defined as a sign that distinguishes the geographical origin, material, type of manufacturing, or other common characteristics of goods or services. The owner can either be an association of which those enterprises are members or any other entity, including a public institution or a cooperative (WIPO, 2017a).

${ }^{3}$ Such as the World Trade Organization under the Trade Related Intellectual Property Rights.
} 
(Vázquez, Barea, Navarro, \& Ruiz, 2007), food security (Díaz et al., 2008), or territorial development (Boucher \& Reyes, 2011; Lozano \& Aguilar, 2012; Vandecandelare et al., 2010). Furthermore, different studies have shown the role of Gls in socio-economic revitalization of some territories (Amaya-Corchuelo, Froehlich, Aguilar, \& Fernández-Zarza, 2016; Froehlich, 2012; Sacco, Aguilar, \& Velleda, 2013), or with environmental conservation (Amaya-Corchuelo \& Aguilar, 2012; Lozano \& Aguilar, 2010). Social justice, small-scale production, short production and consumption chains (Marsden, 2004; Mauleón, 2001; Murdoch \& Miele, 2004; Triches, 2012), enhancement of markets and singular products (Thomé da Cruz, 2012) constitute, among others, some of the questions discussed in this topic. However, these scientific contributions are deprived of approaches in which the role of institutional density when creating Gls is analysed.

There are experiences worldwide where the production of Gls is seeing varying levels of success, which will depend on the degree of institutional and noninstitutional support. Cases such as the Café de Veracruz (Pérez Akaki \& Pérez Tapia, 2012), Cotija cheese (Barragán, 2017), and the Tequila 4 in Mexico (Bowen \& Zapata, 2009; Rodríguez, 2007) illustrate the current obstacles in achieving the reputation needed to certify a known, but still marginal, origin and finding the right institutional structure required by the certification process. These examples highlight the long process and bureaucratic complexity needed to obtain this label, where interests of transnational companies and treaties among countries compete (Rodríguez, 2007). Furthermore, the high standards that this certification requires, the low institutional support, or a limited market demand for the various products are, among others, certain reasons that may inhibit initiatives (Giovannucci, Josling, Kerr, \& Yeung, 2009). By contrast, the various European examples show the new paradigm of rural development: aiming for quality rather than quantity, marking the transition towards an agriculture with environmental measures, and territorial focus that supports territorial quality (Marsden, 2004; Woods, 2012).

Therefore, it is important to identify the type of support throughout the process, whether it is a grant or any other type of financial funding. However, these have been considered controversial as they draw public aid for certain productive sectors, the exclusion of others, and they have even been subject to lawsuits (Marette, Clemens, $\&$ Babcock, 2008). A common element in the process for request and registration comes from verifying the quality of the product itself, the arrangement of the producers' association-in particular, its numbers and capacity for collective action, its level of operational organization, legal expertise, coordinated supply chains, infrastructure, local regulations, and, of course, public or private support (Belletti, Burgassi, Marescotti, \& Scaramuzzi, 2007; Qui onesRuiz et al., 2016; Torre \& Wallet, 2016; Tregear et al., 2007). So it is fundamental that external support for the creation process of a Gl is present at an early stage, through the entire process and while the product is on the market (Vandecandelare et al., 2010).

Obviously, the social and economic contexts are different in the cases studied here that includes the same institutions whose are involving in these programs, as well as in the nature of the different founds. Although the Mexican government is the sole responsible party for developing, announcing, applying, and administering its own public policies based on its international agreements, in particular, the North American Free Trade Agreement (NAFTA) with the United States and Canada; Spain actively participates in the elaboration, management, control, and administration of its policies, always taking into account the interests of other countries that make up the supranational organization of the European Union (EU). Although, in Latin America, programmes were mainly designed on the basis of institutional credits and government policies (Appendini, 2014; Chiriboga \& Plaza, 1998; Liendo, 1997); in Europe, changes were led under the Common Agricultural Policy (CAP) and its new philosophy of European Development Policy (Ploeg, 2000, Massot, 2012).

The institutional framework becomes a core element of analysis to understand the success, stagnation, or defeat of a Gl. From this view, the research questions of this paper are as follows: Does the degree of institutional support

\footnotetext{
${ }^{4}$ The tequila, a symbolic product from Mexico, illustrates the forced entry of a traditional product into internationally established quality standards. The certification of its $\mathrm{Gl}$ was done under the pressure of large tequila businessmen, marginalizing small producers with a lack of resources for meeting the criteria for the new quality label.
} 
determine the initial and long-term success of a product with a GI? What is the role of the producers' association in this initiative? To answer these questions, we analyse two case studies, one European and another from Latin America. Both, the Iberian Ham DOP in Spain and the Chorizo in Toluca Valley in Mexico, represent two quality agrifood products that are involved in different socio-political frameworks, with diverse institutional density and public policies supporting their certification labels.

\section{I MATERIALS AND METHODS}

The methodology used was mixed, and it combines both quantitative and qualitative techniques, as well as the use of primary and secondary documentary sources. Fieldwork was carried out through a sample of 72 semiscripted in-depth interviews applied in both case of studies with cattle breeders, manufacturers, producers, consumers, representatives from the PDO, public institutions, and technicians. In addition, a discussion group was set up in Mexico composed of seven technicians directly involved in the implementation of rural policies. More specifically, they were working for two governmental agencies in charge of these issues: the Secretaría de Agricultura, Ganaderia, Desarollo Rural, Pesca y Alimentación (SAGARPA ${ }^{5}$ ) and the Instituto Nacional de la Economia Social (INAES). Such data allow the comparison of the situation in two different geopolitical zones with an unequal degree of institutional involvement when tackling territorial development. The analysis of results constitutes a step forward in the treatment of data obtained in different areas of fieldwork corresponding to various projects carried out between 2009 and 2016.

Moreover, and given the nature of the situation in Mexico, collaboration was established with the Territorial Work Group who call themselves ProChorizo. Members of the group worked on territorial intervention from the private sector, with the premise of advising producers and managing a GI for the chorizo of Toluca Valley. The fieldwork was carried out through a methodological approach based on Participatory Action Research, where they worked closely with the local actors in the area. In this way, they could delve into the problems caused and into their experience in private management.

Concerning the quantitative approach, two samples were obtained: on one side, $n=204$ lberian ham producers from south-western Spain, and on the other, $n=55$ chorizo producers from Toluca Valley in Mexico. Data were obtained via Computer Assisted Telephone Interviewing, Computer Assisted Web Interviewing, and Paper and Pencil Interviewing. Furthermore, qualitative data were collected and associated with the perception and assessment of different social actors about the creation of agrifood quality certification labels.

\section{I RESULTS: A NEW RURALITY WITH TWO SCENARIOS OF PUBLIC POLICIES}

\section{1 | Towards productivism and competitiveness in Mexico}

When speaking about Gls in Mexico, it is necessary to provide a historical summary on the institutional density linked to the agricultural and livestock sector as it reveals the dynamics of these food quality labels within this context. In this way, international guidelines have permeated rural Mexican context and respond to global dynamics, a path outlined by the market and free competition that has characterized the Mexican model. Since the Green Revolution, this region has chosen a clear productivist ${ }^{6}$ orientation (Pichardo, 2006). In the mid-20th century, the agricultural

\footnotetext{
${ }^{5}$ Secretariat of Agriculture, Livestock, Rural Development, Fisheries and Food.

${ }^{6}$ In this paper, the productivist model implies the triumph of the agricultural technification and industrialization process started after the Green Revolution. Therefore, this process unties societies from their territory, homogenizes production practices, the use of agrochemicals increases, loss of transformation know-hows, and, above all, it maximizes territories' retrievable value. In the Mexican case, this process was endorsed by international agreements that facilitates land concentration and the entry of transnational corporations (Alonso 2014).
} 
sector prevailed over all other sectors with private credits generated through guarantees and promotion funds for agriculture and development. In 1975, the Banca Nacional de Crédito Rural became a single public organism for agricultural funding in an attempt to revive the Mexican countryside (Durán, 2014).

Since 1983, in Mexico, as well as in other Latin American countries, the transition towards the neoliberal model began (Herrera-Tapia, Lutz-Bachère, \& Vizcarra-Bordi, 2009). However, although in South American countries a tendency towards primary economies arose, Mexico became the platform for exports to the United States (Guillén, 2012). Later, despite the fact that reorientation towards Rio 1992 was being discussed worldwide with a view to territorial and sustainable perspectives, Mexico decided to follow the productivist and extensionist ${ }^{7}$ model in which neither territorial competitiveness nor sustainability appeared among public goals (Ekboir et al., 2003).

Although in other countries, territory and territorial competitiveness started to be discussed (Lider, 1999). In 1994, México entered the NAFTA and the effects of agricultural and commercial liberalization brought new schemes with regressive effects into the rural income distribution (de Ita Rubio, 2003). In order to foresee the negative effects of the NAFTA, compensation support was addressed, aimed at coping with agricultural subsidies that other member countries of the agreement had previously implemented. This programme called Programa de Apoyo al Campo (PROCAMPO), whose guidelines were based on raising productivity in the country by increasing the economy's potential growth and helping families' welfare (SAGARPA, 2016). Strategies such as the implementation of technical advice, demonstration plots, and training accompanied these programmes. However, they had little or no impact (Santoyo, Aguilar, Altamirano, \& Rendón, 2010).

Later, it was only during the first decade of this century when topics on rural development were being contemplated (Dussel, 2002; Herrera-Tapia et al., 2009), and as it happened on most of the rural scene worldwide, México started the 21st century with a territorial vision of rurality. SAGARPA incorporated the Ley de Desarrollo Rural Sustentable in 2001. This law allowed the replacement of agricultural policies by incorporating other economic activities in which the elimination of centralism and the promotion of local proposals were contemplated (Méndez, 2006). Its implementation required the design of a new institutional chart. Its main goal was to encourage production and incentivize competition among agricultural, livestock, aquatic, and fishing activities within a territory through a transversal, inclusive, and environmentally sustainable approach. Thus, the Consejos de Desarrollo Rural Sustentable were created to coordinate and promote the governmental participation of the 13 Secretarías, together with civil society and private sector representatives. In this way, the 32 Federative Entities, the 192 Rural Development Districts, the 713 Centros de Apoyo al Desarrollo Rural, ${ }^{8}$ and the 2,393 municipalities that constitute the Mexican governmental administration were assembled at the national level.

Each Federal Entity is under the obligation to apply this SAGARPA's policy and certain of them, such as the State of Mexico, ${ }^{9}$ relies on privileged abilities that allow them to reach agreements. However, this does not mean that there are positive impacts in all cases. Public policy in Mexico was locked into productivism and extensionism. Governmental programmes were limited to the agricultural sector without considering the power of local knowledge, which would allow for the strengthening of activities such as craftwork, agribusiness, or tourism that diversify the activities of rural families and innovation in the sector (Herrera, Rendón, \& Ulloa, 2015).

Despite the evolution and inclusion of the rural and territorial perspective, public policies continued with the same form of dispersion or diffusion. External technicians were hired for short periods-less than 12 months. All in all, these were public aids that did not strengthen the local level and maintained the ideology of political clientelism.

\footnotetext{
${ }^{7}$ Extensionism and productivism share practical foundations. However, the goal of the first is to spread knowledge among people and, since it was implemented in Mexico, it has been based on three fundamental pillars: technical assistance, technology transfer, and training. It is a model of "training and visit" (Santoyo et al., 2010).

${ }^{8}$ Secretariat's Support Centres for Rural Development.

${ }^{9}$ State of Mexico refers to one of 32 Federal Entities, and this is different from the Central Government. In Spanish case, the same administrative level is call Autonomous Communities and there are 17.
} 


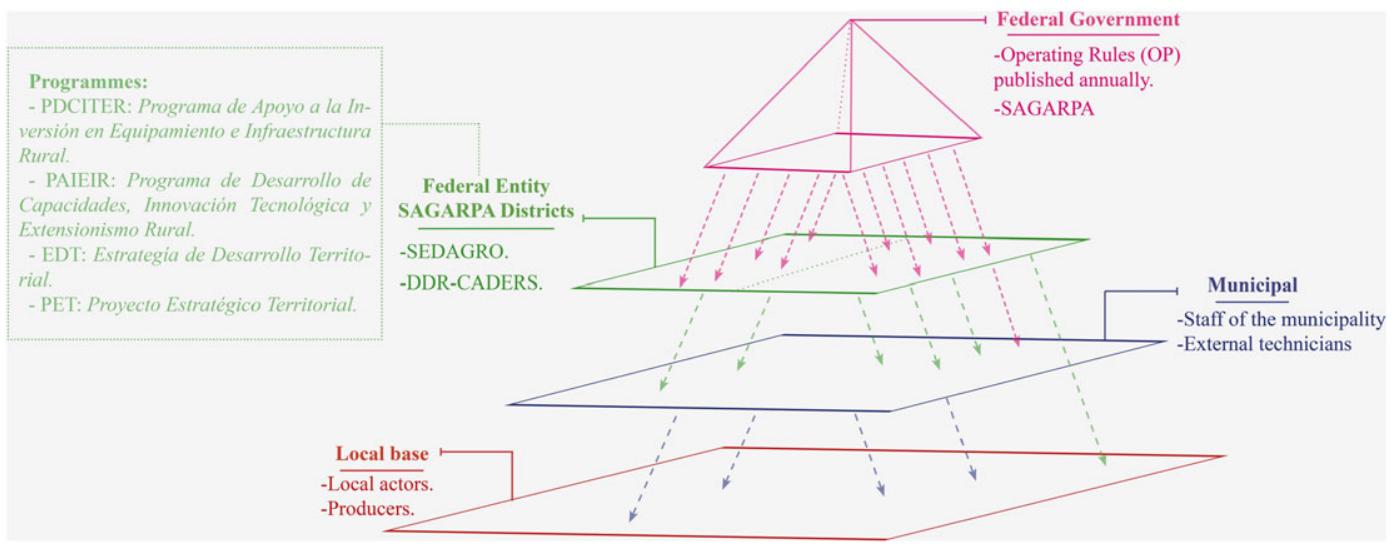

FIGURE 1 Dispersion model of public policies in Mexico and programme absorption. SAGARPA = Secretaría de Agricultura, Ganaderia, Desarollo Rural, Pesca y Alimentación; SEDAGRO = Secretaría de Desarrollo Agropecuario

(Lutz, 2014). As a top-down model mentioned by Torre and Wallet (2016) for the Brazilian case, the design of policies and programmes is often appropriate, but the involvement from different actors changes their nature and even scattered resources become limited; in such a way that upon their arrival to the village or the local base, they have nothing to do with their original design. Thus, the reality is reflected in the interviews:

If you read the regulatory framework, public policies are well explained. In fact, I believe Mexico is one of the countries with the best laws worldwide. But there is something I call the "cone effect." Above, everyone wants things to turn out well ...Then you see people are committed, but as that public policy moves down from the Central Mexican Government to the Federal Entity level, some things are modified in such a way that when they arrive to municipalities, who are presumably the ones needing to be closer to society, each one takes their share and if there are different political parties in power, certain resources do not arrive or get lost on the way. Therefore, when the policy lands and arrives with the producer, it doesn't arrive in tact anymore (Rural Consultancy Manager works to SAGARPA-SEDAGRO-and INAES, 2016).

Yes, good programmes do exist, but a lot of the time the bureaucracy is too much ... Often your application will be rejected if you do not have a 'political godfather'. It has fallen to me to witness how people in charge of assessment do not have any relationship with the countryside; they do not know the sector. Therefore, the provided resources end up not being used or used in other forms ... many programmes go down to municipalities or delegations, but often leaders or those responsible, instead of inviting other people, have their acquaintances as the only beneficiaries (Professional Service Provider who works to SAGARPA -SEDAGRO-, 2016).

Hence, continuity is provided to centralist structures in which systems for rural actors to access incentives become complicated due to excessive bureaucracy. Policies are applied through SAGARPA's regional offices. Each Federal Entity divides the territory into districts. Every year, the Secretaría de Desarrollo Agropecuario (SEDAGRO) ${ }^{10}$ in the State of Mexico and the SAGARPA reached an agreement for the execution of each programme in territorial projects and had a direct impact on the three levels of government: national, state, and district-as well as municipal-as you can see in Figure 1.

There are 11 districts in the State of Mexico where the chorizo production of Toluca Valley is located. Coordination among the three government levels-national, district, and municipal-is used for applying policies in situ through: (a) External technicians employed on a temporary basis, (b) Centro de Apoyo al Desarrollo Rural (CADER),

\footnotetext{
${ }^{10}$ Liaison institution between SAGARPA and the Mexican State.
} 
and (c) staff of the municipality. Strategies for the distribution and promotion of public programmes turn out to be inefficient and become lost within their own logic (Torre \& Wallet, 2016). This top-down and centralized strategy causes lack of resources, assistentialism from an exogenous perspective, and guidelines that are scarcely related to local knowledge and perspectives:

Only in the State of Mexico there is no inter-territorial integration or communication. Just to mention one example, in the north of this Federal Entity there are producers who do not have the raw materials to feed their lambs, whereas in the south of the same Entity they produce sorghum and they often give it away for free because there is nobody to sell it to. This indicates that delegations themselves do not have a database to accurately record their productions, but one thing is true, there are programmes encouraging you to become a government supplier. In this way, discrepancies can be observed. The programme exists, but they do not make the connection or integration. All programmes belong to different sections, each belongs to the agricultural and livestock sector but there is no interrelation (Professional Services Provider who works to SEDAGRO, 2016).

Despite the efforts and changes made within public policies, the agrifood in Mexico prevails with its productivist vision on territoriality. And the lack of institutionalization of a development policy did not facilitate the support to local initiatives (Quispe, 2006).

There are good programmes indeed, but there is no integration as such. In my opinion, the problem of the [Rural] sector stems from political clientelism, vote buying, food provisions and covering momentary and minimum needs. Local actors have not been encouraged to develop their own knowledge. Around 70 or 75 per cent are producers who are not aware of programmes ... Government programmes are intended to keep the population calm with a small grant (Municipal Advisor for the Agricultural and Livestock Sector in the State of Mexico, 2016).

Some programmes are made only for fulfilling their obligation, for politics. The technician is only interested in the signature that validates their job and that's it, without carrying out a study of the region or the conditions of the territory, environment. (Professional Services Provider who works to SEDAGRO, 2016).

Territorial projects are addressed to intermediate producers who can develop innovations have better empowerment and increase their production. These conditions encourage the exclusion of the type of producer who cannot access such dynamics (Herrera et al., 2015). In this way, it is reflected in the paradigm of the discourses among the actors.

Now the SAGARPA representative comes out and says that everything should be corporate, everything should be seen as "agrocluster" but that is not true. The reality in Mexico is different, there are territories where it can be applied and others where it cannot ... a very complex problem is being generated, programmes that do not have integration, technicians who only know how to do their work and cannot see further, producers who do not study thoroughly and are not interested in reviewing both their rights and obligations as citizens, the producer doesn't know how to work in a team either, he has problems with neighbours (Rural Consultancy Manager who works to SAGARPA and INAES, 2016).

This complex scheme of programmes, policies, and paradigms constitutes the framework where strategies for the enhancement of Gl based on certification labels are developed in Mexico. That institutional complexity reveals the difficulties for starting actions. The coordination of grants will remain in the imaginary, and, if agricultural producers have difficulties in accessing them, the agro-industry runs into similar barriers, even more so when it aims to generate a $\mathrm{Gl}$ in such context, as a technician affirms:

In Mexico, the government works under the conceptual framework of Product-System but has forgotten the "local [territorial linkage]" aspect. In this way, when a person or technician tries to integrate 
products linked to the territory into grant projects, those in charge of conducting politics restrain such initiatives and only select the most profitable productive chains. This action continues to ignore the problem over and over again without providing a real solution (Member of EATC ${ }^{11}$ who worked to SEDAGRO, 2016).

\subsection{Institutional connectivity in relation to Gls in Mexico}

The implementation of a GI requires an efficient institutional and governmental structure permitting the guarantee of optimal evolution of the process, and, as some authors have pointed out, this practice is still to be developed in Mexico (Barragán, 2017; Oyarzún, 2005; Oyarzún \& Tartanac, 2002). In the Mexican case, this nomenclature includes the PDOs and CMs. Both are regulated by the Instituto Mexicano de la Propiedad Industrial. The former, under the dispositions of the Lisbon Treaty and its later modifications mentioned hereinafter, where it is highlighted that these Gls belong to the Central Mexican Government (WIPO, 2016). Instead, the latter are subject to rules decided by the group of producers and its use is reserved to them (WIPO, 2017a). Although CMs enter the market as a traditional brand, they function as a Gl; offering guarantees with regard to the manufacturing process, geographical origin, or the quality of a specific product (WIPO, 2010).

However, both policies are addressed to increase the commercial value of local products, putting aside the GIs' nature of encouraging territorial development through certification labels. It is clear that this strategy pursues remarkable business development, as in the case of tequila, ${ }^{12}$ it led to the control of large transnational corporations, monoculture, and the loss of local agave varieties (Valenzuela-Zapata, 2007), which highlights the contradictions of Gls in Mexico (Bowen \& Zapata, 2009). The second PDO, registered in 1994, was for Mezcal. It was also promoted by large sector operators, which reinforces the idea that the implementation of these quality logos was endorsed by private initiatives rather than public or government bodies. ${ }^{13}$ The CMs case is similar. This is the case of Cotija cheese that, while being under big corporations' control, in practice, it loses its capacity for territorial economy activation. In fact, commercial pressure due to the use of the Cotija denomination determined the refusal of a PDO for this product, even though it met the criteria for obtaining it (Barragán, 2017; Ovando \& Barragán, 2015; Poméon et al., 2011).

Bureaucracy plays a central role in obtaining a Gl, checking requirements that connect the quality of the products with their origin may determine their success, even more so if commercial pressure exists, which can be denied (Barragán, 2009). Discrepancies are notorious. On one hand, Mexico has attended the main treated concerning Gls (Pomeón, 2007). And on the other hand, its public policies are not intended for its real development. Therefore, it is an Industrial Property Institute such as Instituto Mexicano de la Propiedad Industrial who has the responsibility to make the final decision on a GI (Barragán \& Linck, 2011). In this way, CMs have become the legal mechanism most widely used in Mexico ${ }^{14}$ for agrifood products with territorial quality that could have met the criteria for seeking a PGI (Pomeón, 2007; Poméon et al., 2011). In some cases, these Gls have worked well and in other cases, they are far from being what they could have been due to situations external to those involved, as is the case of Cotija cheese (Barragán, 2017; Barragán \& Linck, 2011) or tequila itself (Bowen \& Zapata, 2009; Rodríguez, 2007; Valenzuela-Zapata, 2007).

\footnotetext{
${ }^{11}$ Equipo de Asistencia Técnica a Consejos de Desarrollo Rural Sustentable.

${ }^{12}$ This most renowned GI from Mexico arose from major tequila producers who pressured the Mexican Government to register tequila in international treaties. Their goal was to prevent small producers from commercializing their product under the denomination of tequila and, for this, they obtained the support of SAGARPA (Rodríguez, 2007).

${ }^{13}$ For each of these PDOs, regulation defines a legal framework for its implementation, terms of use, controls, sanctions, and so forth. The Industrial Property Law of 1994 and the official Mexican Standard, NOM, define these standards, characteristics, and production and elaboration conditions for various products (Barragán, 2008; Pomeón, 2007).

${ }^{14}$ In the State of Michoacán exist more than $40 \mathrm{CM}$.
} 
TABLE 1 Employment generated in chorizo producing companies (2016)

$\begin{array}{lcccc} & \text { Total workers } & \text { Total men } & \text { Total women } & \text { Total average } \\ \text { Frequency } & 378 & 263 & 115 & 6,87\end{array}$

Source: data retrieved from fieldwork.

This is the context of the study case for the chorizo from Toluca Valley. It is a quality food product, which has continued its historical legacy of the colonial miscegenation and nowadays is seen as the symbol of the State of Mexico and could obtain a Gl. But this product does not hold any $\mathrm{Gl}$, and their production has persisted despite unfavourable conditions. However, this product certainly represents a production chain of low impact, but with high identity values. It generates employment (see Table 1) and local cooperation and working networks, and in addition, preserves cultural and historical elements. Moreover, and this is the most important idea to highlight, this product is directly related to the employment of more than 600 touristic restaurants located around the production territory, within a peri-urban area close to Mexico City. Within this dynamic, as well as the cultural benefits of its conservation and reproduction, the creation of indirect jobs can also be observed, such as cooks, waiters, tortilla sellers, and managers, among others.

The continuity of this activity is not due to the receiving of institutional support, but to two fundamental reasons expressed by Fernández-Zarza, Quintero-Salazar, Dublán, and Viesca (2011): (a) their resilient attitude towards the market and (b) the distribution and solid positioning of the product in the network of tianguis ${ }^{15}$ in Toluca Valley. These spaces are placed within the dynamics of short food chain commercialization and proximity relations. At this point, it is right to address the idea that, for many small-scale producers such as this case study, short chain has proven to be the right pathway, where local actors have strongly controlled their own markets. Hence, direct selling prevails between the producer and the consumer through a relationship of trust. In addition, this type of selling arranges the main clients in order of importance, such as taco and tortería shops, ${ }^{16}$ restaurants, butchers, and distribution companies.

With the socio-political context previously mentioned, and a first impression when doing fieldwork in the area, it might seem that producers work outside legality. But nothing could be further from the truth. They are registered according to Mexican Law (see Table 2), as in the case of Spain, in which all acorn ham industries have a register. Unfortunately, although they are paying their taxes, public policies addressing capacity building have not been designed.

Nevertheless, among the activities of these producers, there is no type of strategy seeking to enhance their product or profession as well as their social and cultural recognition. There are not measures helping to verify the product quality for the consumer or verifying production hygiene standards, among other actions that would provide the product with greater confidence. However, there are producers who incorporate some technological innovations such as electric mills, electronic stuffers, cold chain, freezer, stainless steel workbenches, and uniforms for workers, among others. But $80 \%$ of these initiatives seeking to strengthen the production system are their own initiatives. Only $3.6 \%$ of producers have a specific chorizo label, commercial brand not $\mathrm{Gl}$, the remaining $96.4 \%$ do not use any type of certification that ensures quality for the consumer. Among those with a brand, it is due to their own initiative rather than a policy or public programme.

In this case, there was a proposal for registering a certification quality label, and it emerged from a private initiative (Fernández-Zarza, 2017). Unfortunately, it was stopped for different reasons highlighted in the same paper.

\footnotetext{
${ }^{15}$ Read "tianguis" as a space or local/regional market where direct producers, farmers, or artisans assist to exchange or commercialize their products. Producers are set up by area and type of product, the space is organized by an Organization Committee and it takes place mainly on one particular day of the week, and chorizos are found in this market, an optimal informant platform for its commercialization.

${ }^{16}$ Both are places to sell traditional Mexican food.
} 
TABLE 2 Classification of producers by company type (2016)

\begin{tabular}{cccccccc} 
& $\begin{array}{l}\text { General } \\
\text { partnership }\end{array}$ & $\begin{array}{l}\text { Public limited } \\
\text { company }\end{array}$ & $\begin{array}{l}\text { Small } \\
\text { taxpayer }\end{array}$ & $\begin{array}{l}\text { Natural person } \\
\text { with business }\end{array}$ & $\begin{array}{l}\text { Other type of } \\
\text { register }\end{array}$ & $\begin{array}{l}\text { Not } \\
\text { registered }\end{array}$ & $\begin{array}{l}\text { No } \\
\text { answer }\end{array}$ \\
Percentage & 1.8 & 9.1 & 38.2 & 3.6 & 18.2 & 23.6 & 5.5 \\
\hline
\end{tabular}

Source: data based on fieldwork.

However, in summary, this experience started with the diffusion of the action plan created by the Territorial Work Group, who call themselves ProChorizo, ${ }^{17}$ among producers of the Toluca Valley region. It started with presenting work goals to be achieved, its aims, contributions, and benefits that could be obtained if they participated (Fernández-Zarza, 2013; Fernández-Zarza, 2017).

The second phase focused on listening to producers' needs in order to establish the first common work goals. With a methodology based on participatory workshops, the first objective was achieved through the registration and creation of the Association of Traditional Toluca Valley Chorizo Producers A. C. It was firstly composed of five chorizo producers from different parts of the production area. However, one of the main characteristics of Mexican producers is that they do not have the habit of working together in pursuit of a common goal. This led to the organization not working efficiently and not initiating a solid process for registering a CM (Fernández-Zarza, 2013).

Better results were obtained by other collective initiatives, in particular, the Chorizo Fair was especially important. It was held in Toluca city in 2012, with a later edition in 2013, and it was a main event for the enhancement and diffusion of the product to achieve it, networks for working and collaborating with government institutions and private companies ${ }^{18}$ were set up from a bottom-up perspective. Later, the lack of interest at a municipal political level led to the suspension of later fair editions in subsequent years and, to date, it has not been held again. In this sense, as an alternative strategy to the lack of support from the municipality of Toluca, this government level was skipped and an attempt to access ASERCA's programme was made. ${ }^{19}$ Unfortunately, in most cases, those who get this material support are ones who already have "the know-how" and/or relevant "social and political connections." For that reason, it is very hard for them to get any institutional support. The motivation behind this collective work was suffering to the point of holding back later efforts and only participating in generic food fairs held later in Toluca. $^{20}$

The lack of support on the part of the public administration and individual vision from producers stopped what could have become a way of promoting a local product. This confirms the asymmetry of Mexican top-down politics and how difficult it is to continue with these initiatives. When they are not involved in any protocol or administrative chronogram to obtain concrete support that could allow the setting up of local projects in the longer term. Another

\footnotetext{
${ }^{17}$ This TWG was in charge of gathering information and requirements for registering the CM. However, the team support was altruistic, leading to a complication of the monitoring process. As a consequence, no CM registration has since been achieved. This is different in Spain, where LAGs have their own resources for management, distribution, and assistance/support during the Gl's registration process.

${ }^{18}$ Toluca Municipality through the Tenth Department, Tourism Secretary of the State of Mexico, Crafting Promotion Institute of the State of Mexico (IFAEM), no-governmental institutions such as Tláloc Foundation, Toluca Group, Modelo Museum of Science and Industry (MUMCl) and the Autonomous University of the State of Mexico via the Rural, Farming and Livestock Sciences Institute, Faculty of Political Sciences and Faculty of Architecture and Design, besides private institutions as Cariocas, Toluca Football Club, and Super Kompras.

${ }^{19}$ The ASERCA programme is part of the Operating Rules (Reglas de Operación) published yearly in the Official Gazette of the Federation (DOF). The programme component is included in Article 17 of the component "Incentives for commercial promotion and export enhancement" within the first section referring to "Commercial promotion projects" through the "Promotion, management and procedures of Collective Marks," in addition to the component "Fairs, events, exhibitions, forums, congresses and tastings" (DOF, 2013).

${ }^{20}$ Considering the lack of support from the Municipality of Toluca, it is a paradox that the association representatives were being contacted by a city employee to invite them to events such as generic food fairs.
} 
case of rapprochement between the producer's association and a government institution was obtaining support for capacity building in hygienic food handling within the PAIEIR from SEDAGRO. However, as the Chairman of the association mentions, the support did not continue due to excessive bureaucracy and the fact of not knowing anyone within the institution, combined with the fact that in 2014, SAGARPA's Operating Rules are changing and new guidelines are being considered.

In the end, communication between institutions is asymmetric and curbs producers' work. This being the case, alternative institutional channels are expected, but they are far off providing direct support as they are embedded within a bureaucratic process that is difficult to understand by these types of actors. In addition to this, the sociological context in which this producer's collective is located must be taken into account, as the geographic dispersion of their business in Toluca Valley causes difficulty for the interconnectivity to allow, on one hand, the social arrangement of a common project and, on the other hand, the improvement of actors' capacities and a singularity certificate that identifies the quality of Toluca Valley's chorizo.

\subsection{Iberian Ham PDO and institutional support. The case of EU}

The European case started with the application of the CAP that since the end of the last century has been outlining and funding the transition from a productivist logic towards a post-productivist model in the current rural territories. A process characterized by the shift towards a new concept of agriculture, according to new concerns on social and economic sustainability, environment, and food security (Bowler \& Ilbery, 1997; Lozano \& Aguilar, 2010).

The first stimulus of this new era began in the 90s with the LEADER Programme initiatives (Ray, 2000). The territorial approach started with them being the substantial element of development programmes. The new philosophy dictated that the territory would become a resource itself (Esparcia, Escribano, \& Serrano, 2015). From this logic, new elements such as history, environment, and culture were incorporated as the backbone of all rural development programmes, and from then on, with actions based on multiple activities and the promotion of activities that were different to the rural ones. Under this new logic were approved a new European framework for quality agrifood products to be adopted for all EU member countries. In 1992, two key regulations related to the subject of this study were established: (a) the Regulation (EEC) 2082/92 on PDOs and PGIs and (b) the Regulation (EED) 2081/92 on TSGs (Cáceres, Cruz, Rodríguez, \& Rubio, 2004). This was also the time where the promotion of development and protecting agro-industry products were applied in different European countries.

Strategies such as PDO, PGI, and TSG are now established and very normative figures through tight regulations that are full of controls, whose objective is to inform and ensure product territorial quality for the consumer (Fonte, Acampora, \& Sacco, 2006). However, in order to be under the protection of these labels, it would be necessary to adopt a set of regulations and a collective approach involving a protection regime that simultaneously guarantees fair competition conditions among producers. This helps products to enjoy greater credibility and quality in the eyes of the consumers. Such labels not only represent an already significant part of agrifood exports but they are also a means for agrifood industry development in agricultural economies. In general, countries having correctly implemented Gls have experienced positive changes in the development of the territories possessing products with specific characteristics. Hence, wines, spirits, cheeses, processed meats, and agrifood products with certification by PDO or PGI generally find a suitable means for their promotion and protection.

Iberian Ham PDOs in Spain started to appear in the 80s and there are four nowadays: Guijielo, Dehesa de Extremadura, jamón de Jabugo, and Valle de los Pedroches. Obviously, these labels for Iberian Ham PDOs belong to a greater production sector, the Spanish pig meat sector, which during the years 2012, 2013, and 2014 slaughtered 45.5 millions of pigs. ${ }^{21}$ Among them, the Iberian breed barely reached two and a half million, which is $5.5 \%$ of the

\footnotetext{
${ }^{21}$ http://www.magrama.gob.es/es/estadistica/temas/estadisticas-agrarias/ganaderia/encuestas-sacrificio-ganado/
} 
overall pig production. The Iberian pig stock is concentrated in the Autonomous Communities of Castille and León, Extremadura and Andalusia. Iberian pigs certified by any of the four PDOs represent a small percentage that barely reaches $2 \%$ of the total of this particular breed. Moreover, only $26.5 \%$ of Iberian ham manufacturers belong to a PDO. The rest do not certify their products. This small $26.5 \%$ is divided among the four Iberian ham PDOs (see Figure 2). Paradoxically, it is in this reduced segment of certified productions where the highest prestige of this product is concentrated, the Iberian ham being considered on the same level as other cultural symbols.

The Iberian ham sector is the basis for direct and indirect local work because as well as ham manufacturers, it can talk about Spanish ham carvers, Spanish ham bars, ham carving training, or ham packing companies. As per official Spanish registers, this sector generates 8,783 jobs, whereas in collected data from fieldwork, there were 4,340 jobs registered in 2015 (3,152 men and 1,188 women). Besides production territories, it is easy to find other activities coming from ham manufacturers (see Table 3).

These production processes largely depend on variables such as existing regulation and the diversity in agents involved in this production chain: breeders or producers, manufacturers, suppliers, inspection and certification companies, administrators-local, regional, provincial, autonomous, state, European-PDO regulatory councils, agricultural organizations, other organizations in this sector, research centres, and even the consumers themselves. Nevertheless, according to work goals, it is worth reflecting on and describing the role of main agents during the creation of quality logos, who supported their rise from the public or private level.

Institutional support was decisive, with a focus on economic, commercial, administrative, and legal incentives. They all came together, first with the corresponding regional governments (Castille and León, Extremadura, and Andalusia) that, with the financial support of the European programmes, encouraged social partnership movements among different actors. This activity is necessary for generating a design for product characteristics and requesting

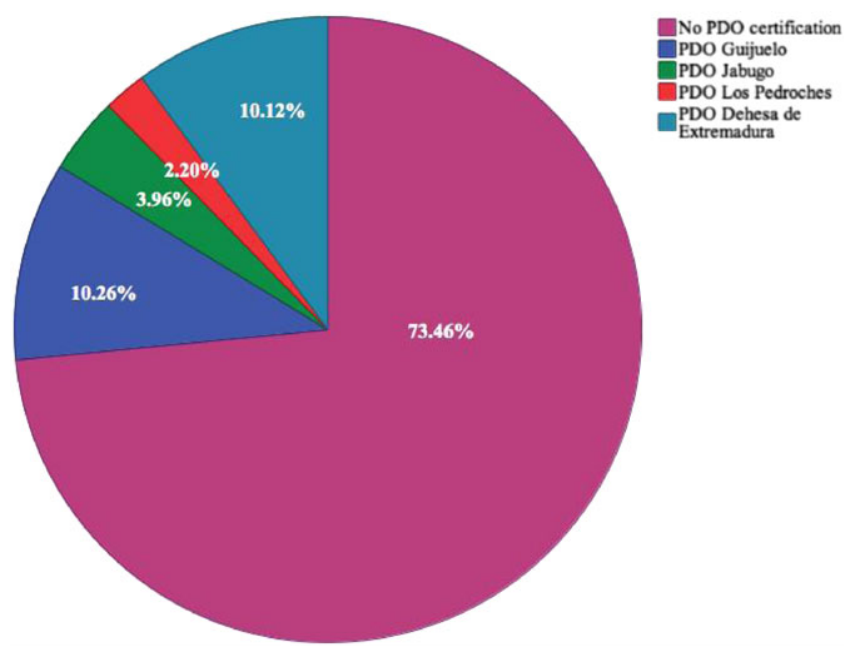

FIGURE 2 Distribution of Iberian ham manufacturers with or without PDO. PDO = protected designation of origin

TABLE 3 Diversification of activities among Spanish ham manufacturers (2015-2016)

\begin{tabular}{ccccccccc} 
& Pig breeding & Pig fattening & Slaughter area & Guided visits & Restaurant & Museum & Ham Tasting & Other \\
Percentage & 39.9 & 48.2 & 25 & 28.9 & 5.3 & 4.4 & 38.2 & 41.2 \\
\hline
\end{tabular}

Source: data retrieved from fieldwork.Note. The final percentage refers to answers provided by producers. Producers could select more than one answer. 
a certification label from the Central Government. From there, the request is referred to meet strict European regulations, as the $\mathrm{EU}$ is the highest body granting the logo.

In fact, and this is an element to be discarded, such institutional support was fundamental to allow producers to achieve their final goal. The process to obtain the recognition of a Gl usually lasts from 6 to 7 years, a long and complex period, subject to a strict bureaucracy and rigid legal constraints that guarantees certainty in logo quality. It would be unthinkable for producers to successfully achieve such process without the support of this network of institutions and public aids. Most importantly, support is maintained after its creation, receiving aids for the local and national commercial promotion, improving infrastructure, market opening, among other necessary support to solve diverse project obstacles that in some cases could be considered as interventionist.

Looking at data provided by PDO websites, some interesting references have been obtained to confirm whether there is any explicit reference to the support received or to the support that they continue to have. It is only in the DOP de Guijuelo 22 case where the current association between the logo itself and the Central Government is clearly expressed. It is shown on the website as follows:

Guijuelo Regulatory Council $(R C)$ is a decentralised body of the Ministerio de Agricultura y Pesca, Alimentación y Medio Ambiente (MAPAMA) ${ }^{23}$ and it is made up of breeders and manufacturers. The first steps were made at the beginning of the eighties, when a group of manufacturers and breeders, along with the support and counselling of technicians from the National Institute for Designation of Origin at the Ministry of Agriculture, Fisheries and Food and the Regional Ministry of Agriculture and Livestock at the Autonomous Government of Castile and León, ... and in 1984 the Provisional Regulatory Council was approved, having as its main goal the elaboration of the Regulation, which was approved by the Order 15449 of 10th June .... In September of that year, the first elections were held and the first Regulatory Council was established. In 1996, the Guijuelo PDO obtained the recognition of the European Union. (Official State Gazette 13-VI)

This type of support provided by public bodies cannot under any circumstances be understood without connecting it to the interaction of such bodies with the Regulatory Council (RC) of each PDO. The RCs constitute the management body of each label; they appear when the PDO is at an early stage, and, over decades, their actions have been synchronized and combined with government bodies. Proof of that could be the testimony provided by one of the informants while being interviewed about Dehesa de Extremadura PDO:

... The PDO was created by the Autonomous Government [of Extremadura] from the top, well ... with some knowledge of the sector but there was no [lberian or pig] sector, and part of its success was because there were no big fish ... in Guijuelo, they got the PDO because they are great salespeople, they made the PDO fashionable and 'we do it. Generally, and historically speaking, the PDO has been running for 20 years since its creation, and its evolution from the beginning is that it was created by a group of breeders and manufacturers who came together because they believed that the Iberian pig, in the Dehesa, was a unique product, and that is how it all started. Due to the faith and belief of certain breeders and manufacturers, and it is true that later this escalated, thanks to the good work from breeders, manufacturers, the central administration and RC's own policy, I think it has been progressing substantially and it has gained ground in the national and international market. (Manufacturer, Dehesa de Extremadura PDO)

The central issue is that these initiatives are intertwined in top-down and bottom-up strategies allowing its creation and continuity. However, it seems that the totality of manufacturers is represented, but on the contrary, as businesses under the protection of any of the four PDOs barely represent $27 \%$, in contrast to the $73 \%$ for those not

\footnotetext{
${ }^{22}$ http://origenguijuelo.com/

${ }^{23}$ Ministry of Environment, Food and Agriculture.
} 
included in any certification. ${ }^{24}$ In addition, according to fieldwork, $50 \%$ of manufacturers believe that consumers prefer acorn ham without PDO certification and that only $29.9 \%$ of consumers would opt for one with PDO. But it would be interesting to verify this observation from the manufacturer's perspective with consumers' real opinion.

Beyond these numbers, agrifood products and institutional policies implemented through the Municipality, Local Action Group (LAGs), Autonomous Governments, RC, and other development agents, in alignment with Central Programmes, generate optimal institutional frameworks in the territory for the creation of new multifunctional dynamics such as acorn ham fairs throughout most of the year, carving competitions, carving training courses, touristic initiatives, museums, expertise recovery and conservation, industrial fabric development, capacity building, among other activities that categorized territories to as production museums (Bowen \& De Master, 2011). Also, its implementation highlights contradictions such as the appropriation of local knowledge by transnational corporations (Amaya-Corchuelo \& Aguilar, 2012), the disappearance of small producers who cannot meet the regulations, financial support from private banking, and concerning the use of the Dehesa, intensification of housed-pig production. At the same time, political support of this institutional network-local, Autonomous and Central-is not without any mutual benefit, on the contrary, it seeks political advantages.

Ultimately, it is clear that, and this is the main idea to be highlighted, in the Spanish case of Iberian acorn ham PDOs, they have been and continue to be proof of the variety and continuity of aid and support provided by the main political and administrative bodies of Autonomous and Central Government. Support that is perfectly institutionalized and financed through specific European Structural Funds sustaining the CAP.

The existence of these financial funds is a part of the complex institutional machinery that supports European social politics and encourages solidarity in Europe between the countries. In this case, it supports social and economic development in their various rural territories (Aguilar, 2014). This is done via a dense institutional structure whose vertex is in Brussels, and, from there, it descends to Central Governmental level and then continues towards Autonomous level ending in its local base. Most importantly, for these programmes to reach an execution phase has been necessary in the creation of a dense network of institutions operating in their corresponding levels to which they are connected. These institutions, through their body of experts and technicians, have been in charge of raising European funds for their use in territorial levels, a local level in this case, through the LAGs mentioned hereinbefore, administrative structures at a regional level whose existence justifies European action over rural territories and that acted as privileged intermediaries between the specific local level and the European supranational one.

\section{I CONCLUSIONS}

Talking about a GI not only refers to a trend imposed as new guidelines and requests from citizens worldwide. Global risks and recent food scandals explain this new trend that, as this paper has sought to demonstrate, has become a recurring strategy for local producers, a strategy that gives them a comparative advantage as they are differentiated and singularized from other products when competing in increasingly globalized markets. In order to achieve quality, the convergence of several factors is also necessary that, beyond inherent product nature and traceability, they require an institutional framework to guide and lead the project as well as transforming it into a Gl.

Part of these factors, as outlined throughout the text, are institutional frameworks derived from pre-existing policies and regulations led by corporate power groups and guaranteed and supported by the administration, both at

\footnotetext{
${ }^{24}$ The population numbers of acorn ham manufacturers were taken from various business directories: Agencia Espa ola de Consumo, Seguridad Alimentaria y Nutrición, infobel.com, alimarket.es, dehesa-extremadura.com, origenguijuelo.com, jamondehuelva.es, and jamonlospredoches.es. The principal source has been the General Sanitary Register of Food Businesses and Foods (RGSEAA, as per its Spanish acronym), under the heading "Salting and curing ham." This strategy provided a debugged theoretical framework of 682 producers.
} 
managerial and financial level. Without the existence of this institutional density and its interrelation (enablers), the process would stagnate or fail. This has been proved by the studied cases.

The formalization of these actions will depend on the institutional density degree in which each one originates and is implemented. Choosing two areas, with two linked food products, situated in two completely different geographical areas such as Mexico and Spain has allowed the demonstration of different realities to hide behind the setting up of a project seeking agrifood product quality certification, thus revealing enablers and obstacles. The existence of public policies supporting such initiatives and its implementation in Spain after the 80s, and its absence in Mexico, already reveals a first gap in terms of territorial enhancement, which in Spain is not only institutionalized but also takes on a mainly assistentialist approach. It is true that in Mexico exist a kind of these public aids, and these are published annually. But only those who have knowledge about the process can facilitate their access. Thus, if not accessed 1 year, the next will be very difficult, which discourages potential applicants.

The result of these divergent methods constitutes the second conclusion on that subject: In Spain, despite contradictions that emerged due to the implementation of Gls in the Iberian acorn ham sector, and the small number of manufacturers under the protection of a PDO, development can be observed in the industrial fabric of rural areas, increasing technological innovation, entrepreneurial vision, capacity building in local actors, heritage preservation, and self-employment. On the contrary of Spain case, in Mexico, the absence of institutional policies connected with these types of processes prevents private initiatives from developing a $\mathrm{Gl}$ and, thus, avoiding the assessment of inefficient production systems, scarce innovation and participation in other markets, absence of local knowledge protection, and low enhancement of food products with renowned quality. In summary, these are the obstacles appearing in the process studied. Clearly, these divergences derive from the very nature of both geopolitical contexts of these case studies: that is, a European economic bloc protecting and guiding the Spanish case against a free trade agreement in which national interests determine Mexico's isolated position within NAFTA.

It is true that some progress has been made in Mexico, given that its regulatory and legal context for obtaining certification GI was established in the 20th century, and it is covered by the Intellectual Property Institute where there are 15 PDO registers. However, these PDOs show some differences with regard to European cases as they are agrifood products. Clearly representing production sectors included in international commercialization pathways, or in other words, they are hardly recognizable as small, localized, and territorial productions. These last ones, agrifood productions of lower incidence in large economic figures with characteristics of localized and quality productions, are choosing logos like the CM. This is the case for the chorizo of Toluca Valley.

But the process, and this is a third conclusion, is handled directly by the intervention of the academic sector instead of the government or producer associations. This is a formula shared and employed in other Mexican products in which the absence of support given by institutional bodies connected to the administration is specifically highlighted. The very nature of this collective forms the fourth conclusion: The level and category of the Gl is directly related to the existence and composition of the collective launching the project. This is how enablers are defined, as is proven by the lberian acorn ham case. The fact of being covered by manufacturers and protected by various local institutions-MAPAMA with EU financial support-enables the achieving of the PDO category in all cases. Both factors do not exist in the case of the Mexican Toluca chorizo, which will in the future determine the recognition, or not, of the $\mathrm{CM}$.

\section{ACKNOWLEDGEMENTS}

The authors wish to thank the reviewers for their suggestions, as they have enriched the final version of the text.

\section{ORCID}

Mario Fernández-Zarza (10) http://orcid.org/0000-0002-4919-2571

Encarnación Aguilar Criado (1) http://orcid.org/0000-0003-0212-8377 


\section{REFERENCES}

Aguilar, E. (2014). Los nuevos escenarios rurales: de la agricultura a la multifuncionalidad. Endoxa, (33), 73-98. https://doi. org/10.5944/endoxa.33.2014.13560B2B5B65

Alonso, P. (2014). La transición al pos-productivismo: parques patrimoniales, parques culturales y ordenación territorial. EURE (Santiago), 40(119), 217-238. https://doi.org/10.4067/S0250-71612014000100010

Amaya-Corchuelo, S., \& Aguilar, E. (2012). La construcción de la calidad alimentaria: tradición, innovación y poder en las DOP del jamón ibérico en Espa a. Revista de Economia Agrícola (REA), 59(2), 39-52.

Amaya-Corchuelo, S., Froehlich, J. M., Aguilar, E., \& Fernández-Zarza, M. (2016). Uso de tradiciones culturales alimentarias para la promoción de productos con marcas de calidad certificada. In Livro de atas (pp. 674-683). Universidade de Trás-os-Montes e Alto Douro. Retrieved from https://idus.us.es/xmlui/handle/11441/49443

Appendini, K. (2014). Reconstructing the maize market in rural Mexico. Journal of Agrarian Change, 14(1), 1-25. https://doi. org/10.1111/joac.12013

Barragán, E. (2008). Importancia de las Indicaciones Geográficas para la protección de los productos tradicionales de México. El Colegio de Michoacán, Zamora, México: Typescript.

Barragán, E. (2009). Marca Colectiva Región de Origen a productos Michoacanos hacia la revitalización del patrimonio cultural de los pueblos. Centro de Estudios Rurales: Colegio de Michoacán A. C.

Barragán, E. (2017). Entre oportunidades y obstáculos. Lo que devela el proceso de inserción del queso Cotija artesanal en la economía formal. EntreDiversidades. Revista de Ciencias Sociales Y Humanidades, (7), 84-111.

Barragán, E., \& Linck, T. (2011). Las Indicaciones Geográficas en la nueva cuestión agraria ¿A quién pertenece el Queso Cotija? Revista Espa ola de Estudios Agrosociales Y Pesqueros, 230, 171-193. Retrieved from http://www.marm.es/ ministerio/pags/biblioteca/revistas/pdf_REEAP/r230_171_193.pdf

Belletti, G., Burgassi, T., Marescotti, A., \& Scaramuzzi, S. (2007). The effects of certification costs on the success of a PDO/ PGI. In L. Theuvsen, A. Spiller, M. Peupert, \& G. Jahn (Eds.), Quality management in food chains (pp. 107-133). Wageningen Academic Publishers: Wageningen.

Belletti, G., Marescotti, A., \& Brazzini, A. (2017). Old world case study: The role of protected geographical indications to foster rural development dynamics: The case of Sorana Bean PGI. In W. Van Caenegem \& J. Clear (Eds.), The importance of place: Geographical indications as a tool for local and regional development (pp. 253-276). Springer. doi:https://doi.org/ 10.1007/978-3-319-53073-4

Belletti, G., Marescotti, A., \& Touzard, J.-M. (2015). Geographical indications, public goods, and sustainable development: The roles of actors' strategies and public policies. World Development.

Bertozzi, L. (1995). Designation of origin: Quality and specification. Food Quality and Preference, 6(3), 143-147. https://doi. org/10.1016/0950-3293(95)00013-Y

Boucher, F., \& Reyes, J. A. (2011). Guia Metodológica para la activación del SIAL. doi:https://doi.org/10.1007/s13398-0140173-7.2

Bowen, S., \& De Master, K. (2011). New rural livelihoods or museums of production? Quality food initiatives in practice. Journal of Rural Studies, 27(1), 73-82. https://doi.org/10.1016/j.jrurstud.2010.08.002

Bowen, S., \& Zapata, A. V. (2009). Geographical indications, terroir, and socioeconomic and ecological sustainability: The case of tequila. Journal of Rural Studies, 25(1), 108-119. https://doi.org/10.1016/j.jrurstud.2008.07.003

Bowler, I., \& Ilbery, B. (1997). The regional consequences for agriculture of changes to the Common Agricultural Policy. In CAP and the regions: Building a multidisciplinary framework for the analysis of the EU agricultural space (pp. 105-116).

Brunsø, K., Fjord, T. A., \& Grunert, K. G. (2002). Consumers' food choice and quality perception. Aarhus, Denmark: The Aarhus School of Business Publ.

Cáceres, F., Cruz, J. C., Rodríguez, A., \& Rubio, L. A. (2004). Calidad agroalimentaria y denominaciones de origen. Cuadernos de La Tierra Del Agricultor Y Ganadero, (3).

Chiriboga, M., \& Plaza, O. (1998). Desarrollo rural microrregional y descentralización. Perú: Fondo editorial.

Díaz, C., Gómez, C., Aranceta, J., Contreras, J., González, M., Gracia, M., ... Menéndez, M. Á. (2008). In C. Díaz, \& C. Gómez (Eds.), Alimentación, consumo y salud. Colección de estudios sociales, Fundación "La Caixa."

DOF. Acuerdo por el que se dan a conocer las reglas de operacion del programa de comercialización y desarrollo de mercados de la SAGARPA, Diario Oficial de la Federación (2013). Mexico. Retrieved from http://www.aserca.gob.mx/ comercializacion/reglas/Documents/REGLAS de Operación 2014.pdf

Drivas, K., \& Iliopoulos, C. (2017). An empirical investigation in the relationship between PDOs/PGls and trademarks. Journal of the Knowledge Economy, 8(2), 585-595. https://doi.org/10.1007/s13132-016-0386-4 
Durán, J. M. (2014). ¿Hacia una agricultura industrial?: México. ( pp. 1940-1980). Universidad de Guadalajara: Guadalajara, Jalisco.

Dussel, E. (2002). Territorio y competitividad en la agroindustria en México: Condiciones y propuestas de política para los clusters del limón mexicano en Colima y la pi a en Veracruz. CEPAL.

Ekboir, J., Espinosa, J. A., Espinoza, J. de J., Moctezuma, G., \& Tapia, A. (2003). Análisis del sistema mexicano de investigación agropecuaria. CIMMYT.

Esparcia, J., Escribano, J., \& Serrano, J. (2015). From development to power relations and territorial governance: Increasing the leadership role of Local Action Groups in Spain. Journal of Rural Studies, 42, 29-42. https://doi.org/10.1016/j. jrurstud.2015.09.005

Fernández-Zarza, M. (2013). La Acción Colectiva como base para activación SIAL: El caso del chorizo rojo y verde del Valle de Toluca. IC Agropec. y Rurales.

Fernández-Zarza, M. (2017). Calidad agroalimentaria en México. In Agricultura familiar en Espa a (pp. 254-260). Madrid: Fundación de estudios rurales.

Fernández-Zarza, M., Quintero-Salazar, B., Dublán, O., \& Viesca, F. (2011). Distribución geográfica de la producción y comercialización del chorizo verde en el Valle de Toluca: Base para obtener un sello de calidad territorial. In La ganadería ante el agotamiento de los paradigmas dominantes (Vol. 1). Cavallotti, Beatriz; Ramírez, Benito; Casta eda, Ernesto; Marcos, Carlos; Cesín, Alfredo.

Fonte, M., Acampora, T., \& Sacco, V. (2006). Desarrollo rural e identidad cultural: Reflexiones teóricas y casos empíricos. Santiago. Retrieved from http://www.rimisp.org

Froehlich, J. M. (2012). Desenvolvimento territorial: Produção, identidade e consumo.

Giovannucci, D., Josling, T., Kerr, W., \& Yeung, M. T. (2009). Guía de indicaciones geográficas: Vinculación de los productos con su orígen. Ginebra (Suiza): Centro de Comercio Internacional.

Grunert, K. G. (2005). Food quality and safety: Consumer perception and demand. European Review of Agricultural Economics, 32(3), 369-391. https://doi.org/10.1093/eurrag/jbi011

Guillén, A. (2012). Mexico, an example of the anti-development policies of the Washington Consensus. Estudos Avançados, 26(75), 57-76. https://doi.org/10.1590/S0103-40142012000200005

Herrera, F., Rendón, L., \& Ulloa, C. (2015). La estrategia de desarrollo territorial de la SAGARPA en el Estado de México. In C. Chávez, \& F. Herrera (Eds.), Procesos sociales en el medio rural, Acercamientos teóricos y experiencias de investigación (pp. 65-100). Toluca: Universidad Autónoma del Estado de México.

Herrera-Tapia, F., Lutz-Bachère, B., \& Vizcarra-Bordi, I. (2009). La política de desarrollo rural en México y el cambio institucional 2000-2006. Economía, Sociedad Y Territorio, 9(29), 89-117. https://doi.org/10.22136/est002009188

de Ita Rubio, A. (2003). Los impactos socioeconómicos y ambientales de la liberalización comercial de los granos básicos en el contexto del TLCAN: El caso de Sinaloa.

Lider, O. E. (1999). La competitividad territorial. Construir una estrategia de desarrollo territorial con base en la experiencia LEADER. Innovación En El Medio Rural, 6(1). Retrieved from http://ec.europa.eu/agriculture/rur/leader2/rural-es/biblio/ compet/sub21.htm

Liendo, I. (1997). Teorías del desarrollo, un enfoque y una propuesta de la perspectiva Latinoamericana. In C. G. de I. y E. A. Universidad Autónoma del Estado de México (Ed.), Investigación para el desarrollo rural: diez a os de experiencias del CICA (p. 118). CICA.

Lozano, C., \& Aguilar, E. (2010). Natural, tradicional y de la tierra: La promoción de la calidad agroalimentaria en los nuevos espacios rurales andaluces. Patrimonio Cultural En La Nueva Ruralidad Andaluza, 126-139.

Lozano, C., \& Aguilar, E. (2012). Territorialising organic production: Collective actions and public policies in Andalusia. Sviluppo Locale, 15, 37(38), 45-66.

Lutz, B. (2014). Formación histórica de la sociología rural: Proceso de civilización del indio y del campesino en México (18701960). Sociológica (México), 29(81), 161-197.

Marette, S., Clemens, R., \& Babcock, B. (2008). Recent international and regulatory decisions about geographical indications. Agribusiness, 24(4), 453-472. https://doi.org/10.1002/agr.20173

Marsden, T. (2004). Theorising food quality: Some key issues in understanding its competitive production and regulation. In M. Harvey, A. McMeekin, \& A. Warde (Eds.), Qualities of food (pp. 129-155). Manchester: Manchester University Press.

Massot, A. (2012). Los mecanismos de la PAC 2020: Principales vectores del proceso de reforma en curso. Revista Espa ola de Estudios Agrosociales Y Pesqueros, 232, 13-68.

Mauleón, J. R. (2001). Los canales cortos de comercialización alimentaria como alternativa de los peque os agricultores ante la globalización: El caso espa ol. In XXIII Congreso de la Asociación Latinoamericana de Sociología. 
Méndez, R. (2006). La construcción de redes locales y los procesos de innovación como estrategias de desarrollo rural. Problemas Del Desarrollo, 37(147), 217-240.

Murdoch, J., \& Miele, M. (2004). A new aesthetic of food? Relational reflexivity in the "alternative"food movement. In M. Harvey, A. McMeekin, \& A. Warde (Eds.), Qualities of food (pp. 156-175). Manchester: Manchester University Press.

Ovando, P., \& Barragán, E. (2015). Gestión cultural de un producto artesanal: Queso cotija región de origen. In 2 do. Encuentro Nacional de Gestión Cultural México. Retrieved from http://observatoriocultural.udgvirtual.udg.mx/ repositorio/handle/123456789/247

Oyarzún, M. (2005). Sellos de calidad en productos alimenticios agroindustriales con perspectiva para la peque a agroindustria rural en América Latina. Santiago, Chile: Biblioteca Virtual, Proyecto Regional de Cooperación Técnica para la Formación en Economía y Políticas Agrarias y de Desarrollo Rural en América Latina, FODEPAL.

Oyarzún, M. T., \& Tartanac, F. (2002). Estudio sobre los principales tipos de sellos de calidad en alimentos a nivel mundial. Estado actual y perspectivas de los sellos de calidad en productos alimenticios de la agroindustria rural en América Latina. Santiago de Chile, Oficina Regional de la FAO para América Latina y el Caribe, enero.

Peralta, R. (2010). Diagnóstico de las legislaciones nacionales sobre Indicaciones Geográficas y Denominaciones de Origen de Centroamérica, Panamá y República Dominicana.

Pérez Akaki, P., \& Pérez Tapia, M. (2012). Las denominaciones de origen del café mexicano y sus cuestionamientos como modelo de desarrollo regional. Perspectivas Rurales Nueva Época, (19).

Pichardo, B. (2006). La revolución verde en México. Agrária, São Paulo, 0(4), 40-68. https://doi.org/10.11606/issn.18081150.v0i4p40-68

Ploeg, J. D., Renting, H., \& Brunori, G. (2000). Rural Development: From Practices and Policies towards Theory. Sociologia Ruralis, 40(4), 391-407. https://doi.org/10.1111/1467-9523.00156

Pomeón, T. (2007). El queso Cotija, México. Rapport Réalisé Pour La FAO/IICA Dans Le Cadre D'une Étude Sur Les Produits de Qualité Liée À L'origine En Amérique Latine. Séminaire Réalisé Les 12/13 Décembre 2007 À Santiago de Chile, Chili.

Poméon, T., Barragán, E., Boucher, F., \& Cervantes, F. (2011). ¿ Denominación de origen o denominación genérica?: El caso del queso Cotija. Boucher, F. Y Brun, 2011, 47-72.

Qui ones-Ruiz, X. F., Penker, M., Belletti, G., Marescotti, A., Scaramuzzi, S., Barzini, E., ... Samper-Gartner, L. F. (2016). Insights into the black box of collective efforts for the registration of geographical indications. Land Use Policy, 57, 103-116. http://doi.org/0.1016/j.landusepol.2016.05.021

Quispe, A. (2006). La necesidad de formación de capacidades para la gestión del desarrollo rural territorial. Región Y Sociedad, 18(36), 177-194. Retrieved from http://www.redalyc.org/articulo.oa?id=10203606

Ray, C. (2000). Editorial. The EU LEADER programme: Rural development laboratory. Sociologia Ruralis, 40(2), 163-171. https://doi.org/10.1016/S0338-9898(00)80428-X

Rodríguez, G. (2007). La denominación de origen del tequila: Pugnas de poder y la construcción de la especificidad sociocultural del agave azul. Nueva Antropología, 20(67), 141-171.

Sacco, F., Aguilar, E., \& Velleda, N. (2013). Indicações geográficas e desenvolvimento territorial: Um diálogo entre a realidade europeia e brasileira. Dados-Revista de Ciências Sociais, 56(1), 207-236. https://doi.org/10.1590/S001152582013000100009

SAGARPA. (2016). Programas directo de apoyos al campo. Retrieved from http://www.sagarpa.gob.mx/agricultura/ Programas/proagro/Paginas/Antecedentes.aspx

Santoyo, V., Aguilar, J., Altamirano, R., \& Rendón, R. (2010). Del extensionismo agrícola a las redes de innovación rural. Universidad Autónoma Chapingo (UACH). CIESTAAM, CYTED. Chapingo, Estado de México.

Thomé da Cruz, F. (2012). Produtores, consumidores e a valorização de produtos tradicionais: Um estudo sobre qualidade de alimentos a partir do caso do queijo serrano dos campos de cima da Serra/RS. Tese de doutorado em Desenvolvimento Rural. Porto Alegre: UFRGS.

Torre, A., \& Wallet, F. (2016). Regional development in rural areas: Analytical tools and public policies. Springer. https://doi.org/ 10.1007/978-3-319-02372-4

Tregear, A., Arfini, F., Belletti, G., \& Marescotti, A. (2007). Regional foods and rural development: The role of product qualification. Journal of Rural Studies, 23(1), 12-22. https://doi.org/10.1016/j.jrurstud.2006.09.010

Triches, R. M. (2012). Reconectando a produção ao consumo: A aquisição de gêneros alimentícios da agricultura familiar para o Programa de Alimentação Escolar.

Valenzuela-Zapata, A. (2007). Las denominaciones de origen Tequila y Mezcal y la biodiversidad en el género Agave sp. In CUCBA-Universidad de Guadalajara, Departamento de Salud Pública. 
Vandecandelare, E., Arfini, F., Belletti, G., \& Marescotti, A. (2010). Linking people, places and products. FAO: Quality. Retrieved from www.foodquality-origin.org/guide/guide.pdf

Vázquez, A., Barea, F., Navarro, L., \& Ruiz, P. (2007). La calidad y las denominaciones de origen en los aceites de oliva andaluces. Distribución Y Consumo, 96, 42-50.

WIPO. (2010). Las Marcas Colectivas y las Denominaciones de Origen. Retrieved January 1, 2015, from http://www.wipo. int/edocs/mdocs/geoind/es/wipo_geo_lim_11/wipo_geo_lim_11_6.pdf

WIPO. (2016). Las denominaciones de origen. Retrieved from http://www.ompi.int/lisbon

WIPO. (2017a). Collective marks. Retrieved January 1, 2017, from http://www.wipo.int/sme/es/ip_business/collective_ marks/collective_marks.htm

WIPO. (2017b). Madrid agreement concerning the international registration of marks. Retrieved January 1, 2017, from http://www.wipo.int/wipolex/en/wipo_treaties/text.jsp?file_id=283530

WIPO. (2017c). Paris convention for the protection of industrial property. Retrieved January 1, 2017, from http://www. wipo.int/treaties/en/text.jsp?file_id=288514

Woods, M. (2012). Rural geography. London: SAGE.

How to cite this article: Fernández-Zarza M, Amaya-Corchuelo S, Aguilar Criado E. Institutional density and public policies in two cases of geographical indications from Mexico and Spain. J Agrar Change. 2018;1-19. https://doi.org/10.1111/joac.12276 